\title{
The Crisis of Danbury Fair Mall
}

\author{
Jin Sun Ahn \\ Western Connecticut State University \\ Hanyong Chung \\ Southern Connecticut State University \\ Jung Hoon Kim \\ Southern Connecticut State University \\ Youngbin Kim \\ Western Connecticut State University
Natalie Jungyoun Shin
Drexel University

This case describes the difficult financial situation of Danbury Fair Mall, which is the second biggest shopping mall in Connecticut. After World War II, the shopping mall business had grown fast especially in suburban areas of the U.S. However, the increasing popularity of online shopping caused extensive damage to shopping malls. This case will provide students the chance to think about the past, the present, and the future of the shopping mall industry in the U.S.

Keywords: shopping mall, case study, offline business, Connecticut

\section{HISTORY OF THE U.S. SHOPPING MALL}

In 1956, Victor Gruen, an Austrian-born architect, first opened the Southdale Centre in Edina, Minnesota and it was the first enclosed shopping mall in the U.S. The large, spacious building filled with modern shops and public art was enough to attract people. This kind of modern mall became a community space where people could meet, exchange ideas, and purchase goods and services in warm and friendly environments without needing to venture into the city (Gruen \& Smith, 1960). They brought numerous services and retailers together in a single location in a suburb, something main streets and cities could rarely offer. As the U.S. suburbs grew, the popularity of malls also increased. The growth and development of shopping centers facilitated the migration of the population out of the cities. 
FIGURE 1

THE NUMBER OF U.S. SHOPPING MALLS AND PERCENTAGE CHANGE

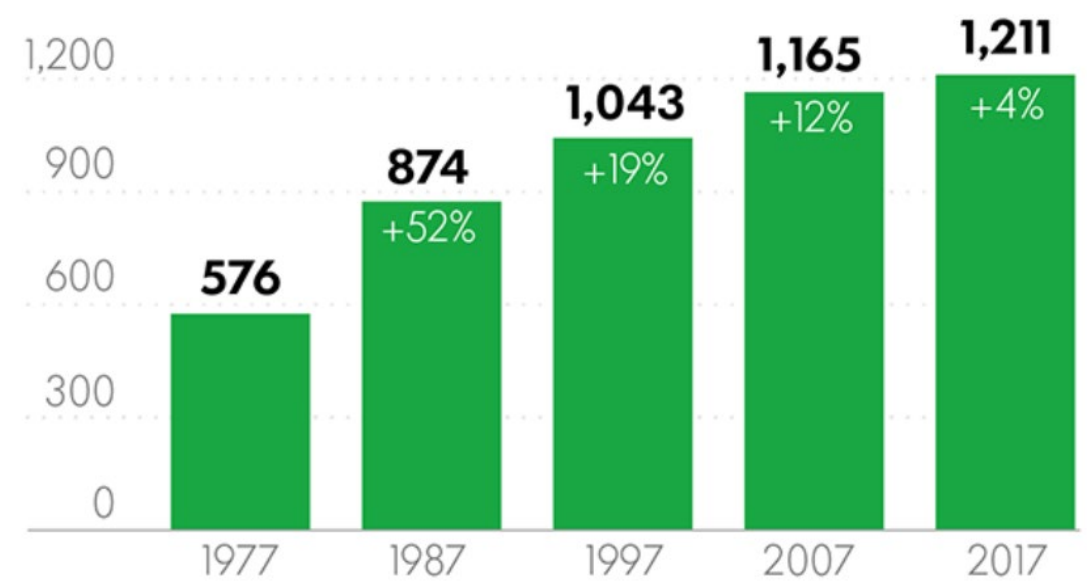

Source: https://www.usatoday.com/story/money/business/2017/06/06/are-us-shopping-malls-endangeredspecies/102488704/

\section{DECLINE OF THE MALLS}

The decline of the U.S. malls began slowly in the mid-2000s. Many department stores and clothing retailers have long failed to offer differentiated merchandise and lost market share to comparable off-price retailers (Cheng, 2020). Importantly, the rise of online shopping and the blow of the recession led to a lot of malls in the U.S. struggling to sustain the costly maintenance. This phenomenon became severe after the COVID-19 virus in 2020.

\section{Rise of Internet Commerce and Online Shopping}

The malls lost out to online shopping in the 1990s. Customers became adept at shopping online and started to feel that shopping offline is inconvenient compared to their online shopping experience. For example, indoor shopping malls require customers to find parking in crowded decks and navigate long and complicated pathways to find what they are looking for. The retailers of the shopping malls began to face persistent negative effects from online shopping.

\section{Economic Downturn}

The Great Recession in 2008 served as a catalyst to the rapid decline in the economic health of malls across the U.S. United States. According to the real estate experts, the percentage of dying malls, also called "zombie malls", had increased significantly from 2006 to 2010. Over 400 malls closed between 2007 and 2009 and the year 2007 is the first time a mall wasn't built in the U.S., something that hadn't happened since the 1950s (Esri, 2014).

\section{COVID-19 Virus Effect}

The pandemic has accelerated a demise that was already underway. Many people tend to work from home and avoid crowded places, leading to a sharp decrease in traffic at the shopping malls. Department stores and apparel retailers that are integral partners of the malls struggled financially and filed for bankruptcy due to the pandemic. This has resulted in a spike in vacant spaces as many retailers could not pay rents, damaging the viability of the malls.

It is expected that 1 in 4 malls and as many as 1 in 2 could eventually close, according to the analysis conducted by Coresight. While top-tier malls in popular locations are likely to survive the pandemic 
damage, the underperforming malls will disappear more quickly, as people bypass them for malls offering more upscale experience or simply opt-out for online shopping (Jones \& Tyko, 2020).

\section{FIGURE 2 \\ CREDIT RATE OF U.S. MALLS IN 2017}

\section{MALLS ACROSS AMERICA ARE AT RISK OF CLOSING}

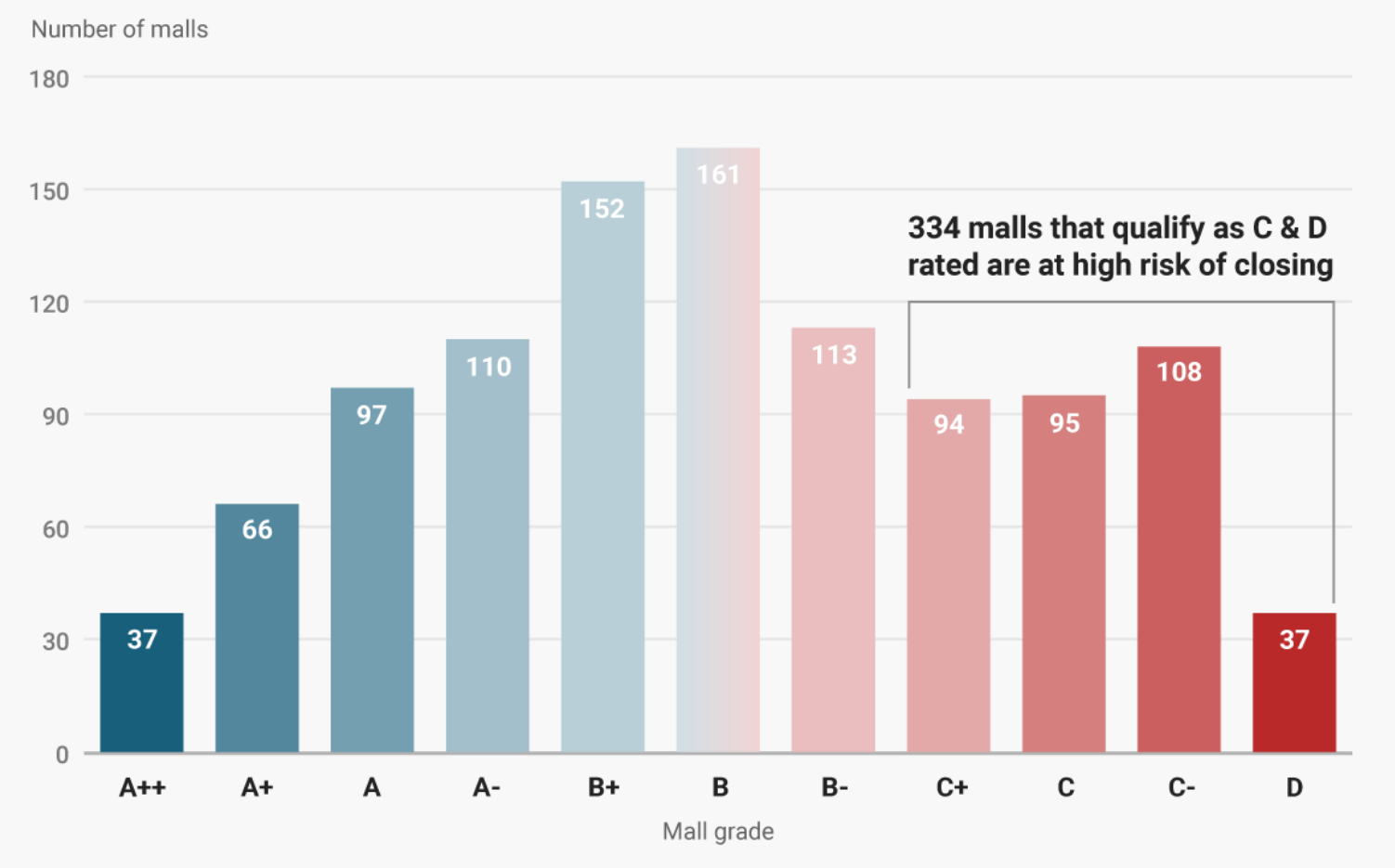

SOURCE: Green Street Advisors

BUSINESS INSIDER

Source: https://www.urbanismnext.org/news/the-blight-of-failing-malls-a-rising-burden-of-e-commerce

\section{HISTORY OF DANBURY FAIR MALL}

\section{The Great Danbury State Fair}

An agricultural fair was held by the town of Danbury in 1821. From 1869, the event became annual and moved to Danbury Pleasure Park. Later, Danbury Farmers and Manufacturers Society bought 100 acres of the park's ground and began The Great Danbury State Fair (the fair, hereafter). Over the years, a threeday event had extended to 10 days. The fair included rides, entertainments, animal booths, food booths, and farm-grown vegetable shops. The fair was suspended only twice in the 112 years of history (1918 due to Spanish Influenza and 1942-1945 due to World War II). Horse and auto races were the two most popular attractions in the early $20^{\text {th }}$ century. In 1946, a banked speedway replaced the horse track and accommodated car races. As the fair became popular, it even resulted in high school students strike in 1946. That year, 1,500 students from Danbury High School refused to attend classes to visit the fair on Friday, which was traditionally called Danbury Day. The fair admitted students for free (ConnecticutHistory.org, 2020). The last fair was held in October 1981, attracting almost 250,000 visitors. Then, it was sold to Wilmorite Corporation for \$25,000,000 andthe new owner opened the Danbury Fair Mall in 1986. 
FIGURE 3

RACE TRACK, DANBURY FAIR, 1884

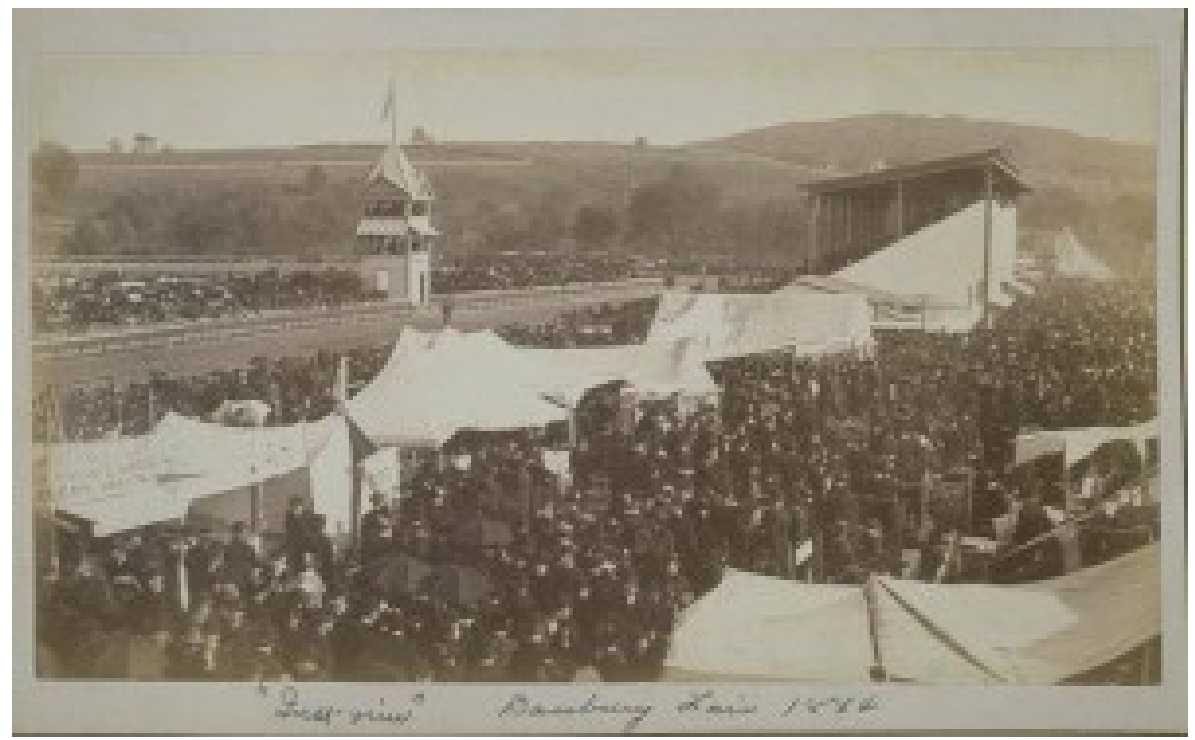

Source: https://connecticuthistory.org/the-danbury-fair-1869-1981/

\section{Danbury Fair Mall}

The Danbury Fair Mall (the mall, hereafter) is an indoor shopping mall located in Danbury, Connecticut. The floor area of the mall is $1,226,000$ square feet, which makes it the second biggest shopping mall in Connecticut. Currently, the mall accommodates over 180 retailers and 7 anchor stores. An anchor store is normally located outside a mall but directly attached. The Danbury Fair Mall has 7 anchor shops such as Macy's, JCPenney, Lord \& Taylor, Primark, Dick's Sporting Goods, Sears, and Forever 21. Every anchor store except JCPenney and Macy's is owned by the mall.

Due to the ever-growing online shopping mall and the COVID-19 pandemic, several shops have been close for months. Sears, Forever21, and Lord \& Taylor closed shops in 2020 and these stores remain close ever since. Several shops like Coach or Godiva shut down their businesses. What makes the situation worse for the mall is that most of these stores stay closed for months or even years. Confronting the pierce competition from online shops and customers keeping distance from the crowd, many retailers are not willing to pay expensive monthly rent.

The current owner of the mall is the Macerich Company. The Wilmorite Management Group sold the Danbury Fair Mall to The Macerich Company in 2005. The Macerich Company is a real estate investment trust, whichwas founded in 1965. As of December 31, 2020, 52 properties are wholly owned or partly owned by the Macerich Company. The Danbury Fair Mall is 100\% owned by the Macerich Company except for two anchor stores including JCPenney and Macy's (The Macerich Company, 2021). 
FIGURE 4

DANBURY FAIR MALL, 2021

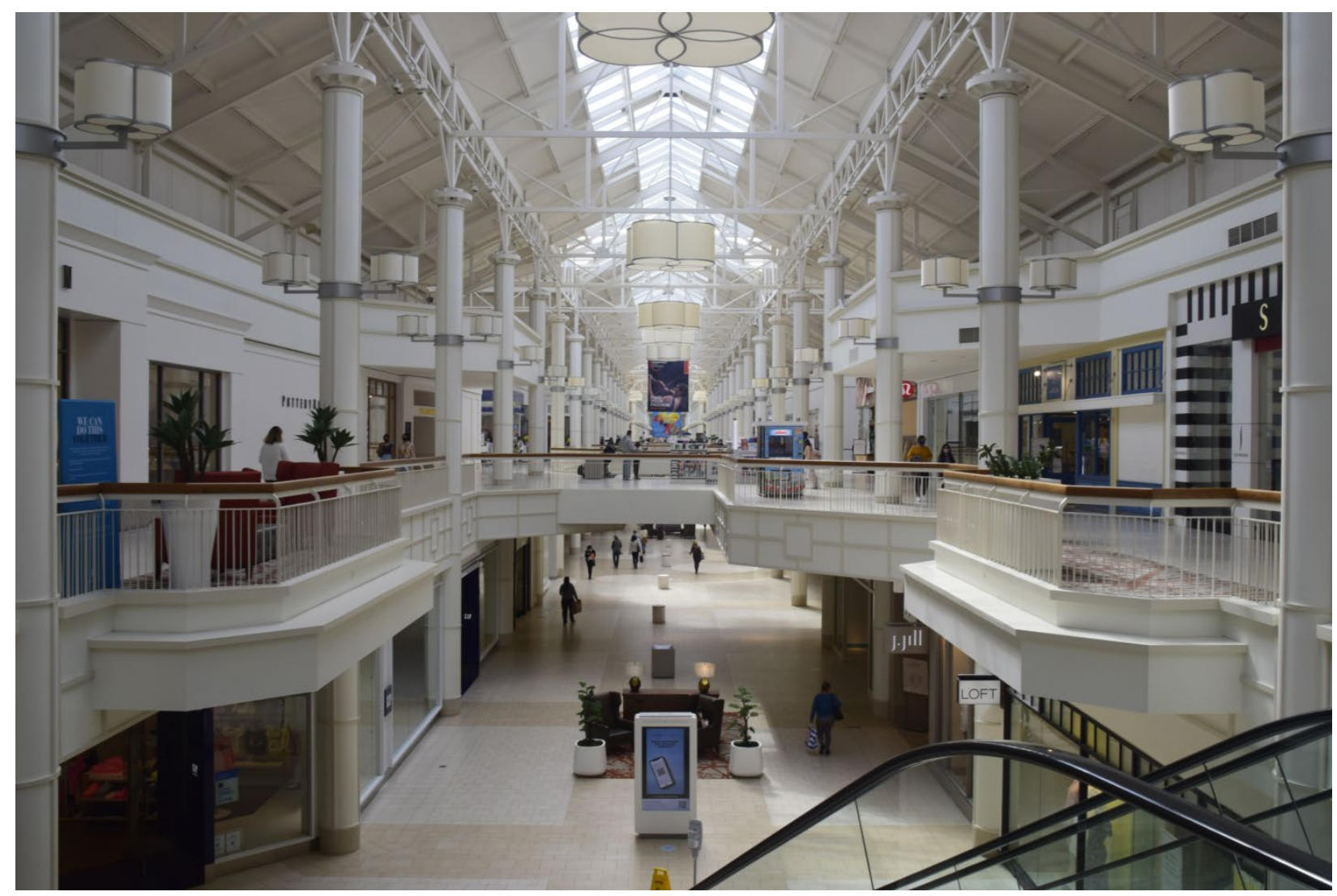

Photographed by an author

\section{HOW TO SURVIVE}

David Yang is an independent consultant who provides advisory services to shopping malls in suburban areas. The management of the Danbury Fair Mall hired him to analyze the current status of the mall. After spending several weeks, David Yang brought three recommendations to the managers of the mall.

Recommendation 1: Today, more and more people buy products from online shops like Amazon. To avoid direct competition with online malls, the Danbury Fair Mall should accommodate more restaurants and food shops.

Recommendation 2: Currently, the Danbury Fair Mall has no off-price shops like TJ Maxx or ROSS. The mall should consider bringing these stores on board.

Recommendation 3: Not everything is available online. The mall can provide its customers experiencebased products like go-karting or live music stage.

\section{QUESTIONS}

1) Discuss the pros and cons of each recommendation which David Yang has provided to the Danbury Fair Mall. 
2) Although some anchor shops are not owned by the Danbury Fair Mall, the closure of these shops may hurt the business of the mall. Why is that?

3) What type of shops is more likely to be affected by competition from online shopping and what type of shops is less likely?

4) If you are the owner of the Danbury Fair Mall, how do you renovate the mall? What do you want to emphasize in spending a limited budget on the renovation?

5) Find the successful/profitable US malls (for example, Aventura Mall in Florida). What type of amenities do they offer? Do you think these features are the drivers that bring people to the mall?

\section{REFERENCES}

Cheng, A. (2020). Coronavirus Will Be 'Final Catalyst' To Weed Out Excess U.S. Malls: Study. Forbes. Retrieved from https:/www.forbes.com/sites/andriacheng/2020/10/08/coronavirus-will-be-finalcatalyst-to-weed-out-excess-us-malls-study/?sh=1ffaaf076642

ConnecticutHistory.org. (2020). The Danbury Fair, 1869-1981. Retrieved from https://connecticuthistory.org/the-danbury-fair-1869-1981/

Esri, N.G. (2014). The death and rebirth of the American mall. Smithsonianmag.com. Retrieved from https://www.smithsonianmag.com/arts-culture/death-and-rebirth-american-mall-180953444/

Gruen, V., \& Smith, L. (1960). Shopping towns, U.SA.: The planning of shopping centers. New York: Van Nostrand Reinhold.

Jones, C., \& Tyko, K. (2020). Shopping malls were struggling before COVID-19 and now have more empty stores: What's next after the pandemic? USA Today. Retrieved from https:/www.usatoday.com/story/money/shopping/2020/12/29/shopping-mall-closures-aftercoronavirus/3862931001/

The Macerich Company. (2021). 2020 Annual Report.

Thomas, L. (2020). $25 \%$ of U.S. malls are expected to shut within 5 years. Giving them a new life won't be easy. CNBC. Retrieved from https://www.cnbc.com/2020/08/27/25percent-of-us-malls-are-setto-shut-within-5-years-what-comes-next.html 